\title{
Calling out to the Faraway: Accessing History through Public Gestures in Howrah, West Bengal
}

\section{Atreyee Majumder}

\section{OpenEdition}

\section{Journals}

\section{Electronic version}

URL: http://journals.openedition.org/samaj/3614

DOI: $10.4000 /$ samaj.3614

ISSN: $1960-6060$

\section{Publisher}

Association pour la recherche sur l'Asie du Sud (ARAS)

\section{Electronic reference}

Atreyee Majumder, « Calling out to the Faraway: Accessing History through Public Gestures in Howrah, West Bengal », South Asia Multidisciplinary Academic Journal [Online], 7| 2013, Online since 15 October 2013, connection on 20 April 2019. URL : http://journals.openedition.org/samaj/3614 ; DOI : 10.4000/samaj.3614

This text was automatically generated on 20 April 2019

\section{$(1) \Theta \Theta$}

This work is licensed under a Creative Commons Attribution-NonCommercial-NoDerivatives 4.0 International License. 


\title{
Calling out to the Faraway: Accessing History through Public Gestures in Howrah, West Bengal
}

\author{
Atreyee Majumder
}

\section{Introduction}

1 Public figures emerge in Indian history of colonialism and nationalism, variously through Chris Bayly's 'townsmen' (1983)-men of influence in north Indian towns, who come to mediate the spread of nationalist ideas, or Sumit Sarkar's portraits of young men expressing the swadeshi vision in marketplaces and through newspapers. ${ }^{1}$ Big men creating and harnessing networks of patronage and influence over caste groups, political parties and other associations (see Bailey 1956, Ruud 2003, Hansen 2001, Ruud \& Price 2010, Mines 1994), figures who influence spheres of ethical and idealistic expression (Da Costa 2009, Bate 2009, Pandian \& Daud Ali 2010) are part of the repertoire of public figures that emerge in the postcolonial era. In this article, I show public figures in the performance and fulfillment of public roles beyond those of support-garnering, patronage, or political mobilization. A range of locally influential figures are spoken of, here, who animate public life in domains like literary festivals, commemoration of births and deaths of historically important persons and public gatherings on the occasion of religious events. The purpose of this article is to show, using ethnographic data, the accessing of history and shaping of historical sensibilities, through public gestures by public figures in the district of Howrah. Referents of history-nationalism, colonialismare appropriated from wider canvases of history and linked, through such public gestures and rhetoric, to being in an immediate, proximate 'place', Howrah.

Between 2011 and 2012, I spent eighteen months in Howrah, conducting ethnographic research on the networks of social and political alliance that spread across the district. My subjects were youth politics enthusiasts, intellectuals, poets, unionists, sports 
organizers, historians, school-teachers and a range of lettered citizens who exercised social and political influence in their neighborhood, town, village, and some across the district. Public life flourished through footballs clubs, literary society, charity institutions, fairs, carnivals and religious festivals. Such public events focalized around influential persons of the area-public figures. These figures could be local intellectuals, teachers, philanthropists or politicians with clear alignments in the system of parties. These figures targeted their spoken and written gestures towards larger entities that extended beyond the spatial limits of Howrah. They linked local events and histories to entities far removed in time and space. I increasingly came to see public gestures as being intricately linked to the material experience of space-being in the rural-urban continuum, and having hosted manufacturing entities for over a century. This article investigates the nature of such gestures.

Historical sensibility in Howrah emerges in response to a century-long exposure to many cycles of manufacture, trade and commerce that struck roots on this industrial riverfront for more than a century. In unpacking this weave of public performance, gesture and rhetoric, I focus on three such figures and their surroundings-Narayan Ghosal, a folk historian and veteran communist, Majid Molla, a mathematician-turned-social-activist, and Hemendro Bandyopadhyay, a one-time journalist and school teacher, who has now taken up historical research and history-writing. These three figures are well-known in their town/village, and are immersed in the networks of intellectual and aesthetic production in the district. They also profess leanings towards political ideologies-one being a communist whose leanings have changed in recent years, one remains a communist enthusiast and one a nationalist who has taken to writing of local histories after retiring as a school teacher.

\section{Rural-Urban Corridor}

Howrah, a district as well as a city-its headquarters, some of whose area comes within the Greater Calcutta region, is organized as a series of towns, villages, and inchoate spaces on the rural-urban continuum connected to the metropolis of Kolkata by two bridges, surface transport (buses and taxis) and ferries on the river. The district grew as part of the hinterland of Calcutta, which provided significant riverside economies for the growth of industries like jute, ship-repair and engineering. ${ }^{2}$ Engineering companies like Burn and Jessop struck roots here as part of the colonial economic program on the lower Hooghly belt, which had the advantageous condition of being close to the port. The Howrah-Panskura trainline, the Amta line (known as the Martin light railway) and roads like the National Highway 6, the Kona Expressway grew in this region, across the $20^{\text {th }}$ century, as part of this landscape's propensity for connection with the wider world through the logic of manufacture. An urban region-Howrah is not clearly mappable in terms of 'town' or 'country'. The national highway, expressways and feeder roads, which connect the region to broader networks of manufacture and market, breathe into connected spatial pockets a sense of speed and associated connections with wider, outer worlds. Such proximity to trade, manufacture, fast-paced conveyance, makes an 'urban horizon' ${ }^{\prime 3}$ available to many seemingly non-urban, even agrarian spaces here. Colonial urban and industrial initiatives are remembered and reconstructed in the public domain -in speech, gesture and writing. These historical motifs are marked as dispensers of 
speed, energy and rhythm of public activity. Public activity progresses as a mirror of history, as charged movement in time.

5 A city of 50 wards, previously designed as an amalgam of five boroughs, Howrah city connected with Calcutta through the pontoon bridge (built in 1874), which was to become the Howrah bridge in the 1940s, and with the Second Hooghly bridge of the 1990s. ${ }^{4}$ A range of public authorities have influence over the design of its urban character. While the city is governed by the Howrah Municipal Corporation, the areas around the bridges and their connecting roads into the district are under the jurisdiction of the Hooghly River Bridge Commission. The Howrah Improvement Trust, established in 1956, plays the role of an implementing agency for many of the urban infrastructure projects-building of roads, expressways, sewer canals-envisaged by the KMDA (Kolkata Metropolitan Development Authority) and other bodies. Some lands are under the Port Authority, as some in Bally, whereas other pockets are under the Railways, I was told as I repeatedly asked about the division of responsibilities of urban planning bodies at the Howrah Municipal Corporation. ${ }^{5}$ The Draft Development Plan of Howrah (2007) describes the district's spread thus:

There are 14 community Development Blocks/Panchayat Samities/157 Gram Panchayets and 763 Mauzas in the District consisting of two sub-divisions i.e. Howrah Sadar and Uluberia having 5 blocks under Sadar sub-division and 9 blocks under Uluberia Sub-division.

The city is eulogized as well as lamented for its large, unwieldy, organic, unplanned body. Its governance proceeds according to the larger planning agenda of the KMDA, ${ }^{6}$ which oversees urbanization of Urban Local Bodies (ULB) in the greater Calcutta region. As an ULB in the greater Calcutta region, Howrah receives funds and delivers the benefits of programs under the Kolkata Urban Services for the Poor Program, as well as central urbanization schemes like Swarna Gram Swarozgar Yojna, Rajiv Awas Yojna and so on.

7 Howrah-city, hinterland and district-is a geography replete with wagon-manufacturing units, dockyards, jute mills, narrow alleys, decrepit libraries. In its economic and political battles as town, village, district, rural-urban corridor, suburb, the traces of energy and pace of a time of busy commerce and attendant urbanity of the early $20^{\text {th }}$ century are showcased through public performance at public events. The dockyards are dormant as the silted riverbed does not permit ships to come upstream to these repair yards. ${ }^{7}$ Jute mills, having endured many turns of the postcolonial industrial vision from private owners and the state, and in response to the global obsolescence of jute as a product, are but tired vehicles of manufacture today. The National Highway 6 cuts through the district's east-west stretch, dispensing some of its speed and urgency to the adjoining landscapes-much of which are completely agrarian in land use. Technological material like cell-phones and outdated desktop computers emerge as significant markers of urban performance on this spatial complex. Cell-phone models from the early 1990s, that do not merit advertisement in cities anymore, are bought, sold and coveted. An economy of obsolete technology thrives on these landscapes, embraced by its residents as key ingredients of their urbanity. In this embrace, urban outcry about the alienating damages of the technological life and the frenzied pace and rhythm of urbanity are narrated in public events. The cell-phone and the computer are objects of wonder and disdain. Young generations are cautioned about their naïve excitement about these objects. Mobility is made possible between towns, villages, Howrah city and across the river to Kolkata by a 
network of buses, trains plying the main towns, aided by trekkers-jeep-like vehiclesthat connect villages and less-connected areas to the major towns.

\section{Public Sphere}

8 In this geography, public life thrives in literary associations, sports clubs, unions, memorial and commemorative services, fairs and such events. A public figure addresses a gathering at such events, in these public domains, and brings home, through the spoken word and gestures, connections with entities far removed in time and space.

9 Much has been written around the bourgeois "public sphere'8 (Habermas 1989, Calhoun 1992, Warner 2002, Fraser 1992, Benhabib 1992) and its variants in the democratic and postcolonial contexts. In the widely read text Provincializing Europe (2000), Chakrabarty shows an ambivalent alignment with relic-forms of subaltern pasts as urban public cultures emerged and were shaped in the teahouses, magazines and chatting practices of $19^{\text {th }}$ century Calcutta. Chakrabarty provides many examples from $19^{\text {th }}$ century Bengali literary and social production-especially, as demonstrated in the practice of spontaneous talk in public places, adda. Adda was a practice in which many anxieties of a newly formed urban self were reflected. These were lives of ambivalence to as well as alignment with the colonial pedagogy of enlightenment and associated values. An ambiguous feeling around new social alignments as well as the condition of being urban influenced tropes of talk and writing, Chakrabarty shows. There are many descriptions of social and spatial formations of civil society in the $19^{\text {th }}$ and early $20^{\text {th }}$ century Bengal (Raychaudhuri 1999, Chattopadhyay 2005). Subho Basu (2004) especially shows the emergence of a peculiar mill-town gentry who maintain ambiguous relations with the colonial officials, while participating in the project of industrial discipline.

Sudipta Kaviraj draws out a home-world motif through which, he argues, Calcutta publics had interpreted the public-private colonial pedagogy. It's the lower-strata, beggar or lessrespectable citizen, who marks membership over places of pablik ${ }^{9}$ nature. This determines an ambivalent and profane public habitation. It is a similar membership of public domains, and the resistance of the pedagogy of Western public-private divides, to which Chakrabarty (1992), in his older essay on urban space in Calcutta, draws our attention in the vignette of a boy urinating on the street as a deliberate mockery of colonial pedagogy of urban civility and economy. All public habitation is not towards the cultivation of an urban public. The urinating boy and the angry mob are not akin to the adda. Public spaces, in Kaviraj's description, carry potential for the weaving of a baroque, unstable, contingent, possibly combative repertoire of spatial habitation as 'public' being. Unruly crowds, mobs, big men, protest groups, moving processions-these entities are painted as carving a different sphere of democratic politics, separate from 'civil society'-to constitute what Partha Chatterjee (2004) would call 'political society'. I wish to show the affective folds that the worlds of public figures assume as these figures use public performance as a tool for establishing historical connection, to expand Howrah and their own location in scale.

11 The nation's entrenchment in deep time is variously spoken about. Manu Goswami revisits the question of production of temporality. Deep entrenchment of the 'nation' form spread with imperial global economy and constituted the "hierarchically organized global space-time' (Goswami 2002: 788). It is the $20^{\text {th }}$ century fragmentation of the nation form that gave way to 'multi-form global space-time' (Goswami 2002: 789). Whereas 
Goswami shows national time being woven in a grid of trade, commerce and political ties that produce a global spatiotemporal frame, I show such global arrangements intimately experienced and narrated by a grade of locally influential figures.

These figures craft and target their public rhetoric and stances at immediate and imaginary audiences, even as they grapple with economic decline and historical anonymity of their surroundings. They lament their current anonymity on the historical stage, where a certain concatenation of actors and events-emperors, colonial officials, nationalist leaders, entities that enact the more urgent stories of power and rule-find luminosity at center stage. They target their public performances at a wider audience in space and time, linking immediate narratives to those of actors who enjoy greater historical luminosity. Such linking aids a scalar expansion, that makes the sensation of being in and narrating Howrah seem a larger enterprise, linked to entities of wider temporal and spatial scale. They invest emotion and moral force in a landscape that is demarcated by the administrative markings of a district within the state of West Bengal within the Indian nation-state-a marking that goes back not further than the 1930s. ${ }^{10}$

\section{Typical Public event}

A good part of my time in Howrah was spent at public gatherings dedicated to the celebration of the deaths and births of the Bengali nationalist canon. In these gatherings, the local order of wise men as well as more distant ones like Tagore and Subhas Bose were remembered in their connections to Howrah. These events would include celebrations of the occasion of the death anniversary of Tagore, the conclusion of the Durga Puja festivities with Vijaya Dashami, birth anniversaries of Swami Vivekananda, Subhash Bose and so forth. The year 2011-the $150^{\text {th }}$ year of Tagore's birth-was observed by a range of events. Such celebration usually included the welcoming of or felicitation of the newly elected local Trinamool ${ }^{11}$ leader.

The prominent figures at such events were loosely in each other's horizon across and beyond the Howrah district. They attended each other's felicitation ceremonies and literary festivals. The first half of my stay in Howrah, progressed in the course of a year of regime change $\mathrm{e}^{12}$ and the Trinamool's accession to power in the state of West Bengal. Many local power alignments had recently witnessed or were witnessing a shift of coordinates of political power. Some associations and clubs were flush with funds. Many events, structured around cultural and religious festivity, affirmed friendship with the newly elected MLA of the Trinamool Congress. The regime change also set in motion a range of narratives around changing relationships with ideology, ethics and membership in history and polity through the rubric of socialism.

The best-attended literary events I went to were at the hundred-year-old Uluberia Institute in Uluberia town. The Dashami gathering was used to declare the publication of Puja $^{13}$ issues of two magazines-Ebong Ma Mati Manush, ${ }^{14}$ published from neighboring block Bagnan, and Shomoy Shakkhor ${ }^{15}$-one from the home turf. A local literary elite appeared as the evening progressed, in starched white dhotis, starchy tangail ${ }^{16}$ saris, thick glasses and embroidered jeans. Speeches followed-some effusive, some acerbic. The dingy room in which old men play cards by daylight, was now lined with plastic chairs with the library bookshelves having been pushed against the back wall. Aluminium-foiled roses and samosa-sandesh ${ }^{17}$ packs were given out to the guests. An expert of folk culture took the podium and invited the attention of the audience to the elitism of academic 
enterprise, emphasizing the role of magazines such as these, in encouraging those who did not operate inside exclusionary academic institutions, to take on the enterprise of intellection.

On another occasion of a literary event of release of an issue of a magazine called Shotta, ${ }^{18}$ also at the Uluberia Institute, Bhaskar, a veteran of literary circles of Uluberia, one of the editors of the magazine, and a communist from the days of yore, rendered a rather acerbic speech. He spoke about the needlessness of all this fanfare, given how simple and humble the effort of the magazine was. He also pointed out several mistakes in the text, which showed editorial neglect and dramatically accepted for himself all blame for the errors. Tapan, a journalist working with a Calcutta-based newspaper, and compere at the event, rued to me about his stories being routinely, brutally edited by ruthless Calcutta editors. He was also annoyed at the refusal of the newspaper to give him bylines, whereas the more-flamboyant motorcycle-riding photographer of the area, was always celebrated.

The local MLA was often present at these occasions. He usually made a short speech of congratulation to the organizers and participants. Some would link the energy of the event to the higher energy of the new government and its tireless elder sister-Didi ${ }^{19}$ (Mamata Banerjee, the Chief Minister) - who needed the cooperation and allegiance of the members of such noble congregations. The speeches and stances rehearsed at these events embraced and attacked many distant actors who were brought into the fold of the lives of those present at the event, despite their real distance, and assumable unawareness of these invocations by Howrah publics. Literary tropes served as vehicles to display one's larger dispositions-humanism, socialism, the sensibilities of an aesthete, even as these occasions provided platforms to meet and greet the MLA and other officials of local state. Nationalist heroes, dead poets, London-America (popular parlance for the West, a node of superior existence and civilization), colonial officials, Kolkata intellectuals-were the more regular interlocutors invoked at these events. Over time, the ethical and aesthetic folds of public life made itself legible to me insofar as I saw Howrah suturing itself to a larger canvas of space and time at each of these events. Allies were sought from among nationalist heroes, humanist poets and Western handles of development and progress, to hold Howrah above the economic and political abyss in which it was otherwise structurally located. A pristine register of 'socialism', a high benchmark of humanism, and a pure, authentic human consciousness were the prerogatives of the members of these gatherings. When I asked them to specifically enumerate the 'ills of this time', they rarely spoke about the more widely recognized ills of the contemporary global time i.e., globalization, finance capital crises, terrorism, Maoism in the Indian red belt, farmers' suicides or agrarian crises. They cited an inchoate crisis, very often couched in socialist rhetoric-poor people being exploited, youth going astray, corruption, general and widespread moral decay.

\section{Claiming Historical Place}

18 The Ghosals are an eminent family of the Maju village, in the Jogotbollobhpur block in north Howrah. Their father was an educationist and writer. Theirs is a well-regarded Brahmin family in Maju. The elder Ghosal, Narayan Ghosal, has written a book on the history of Maju. He writes in many magazines and journals, mostly on folk culture and history of Howrah. These things are getting wiped out, and need to recorded and circulated, he tells me. He gives me copies of his own writing, as well as copies of his 
newspaper Kaushikir Totorekha. ${ }^{20}$ His family has been based in Maju for many generations, and he has resisted the lures of the city.

His brother, Debu, joins in the discussion. He says he was a jatra ${ }^{21}$ personality as also an active member of cricket in Maju. He had coached many boys and had been a player himself. Because, the middle-classes had less children now and were more ambitious for their children, people were less keen to send their kids to participate in contact sports. Football had given way to cricket. The sports field was the platform for youth to become organized. This energy bred fraternity, community spirit and nationalism. It later translated into social and political service. People are currently more invested in individualistic pursuits than they were in days of yore. Today's youth have woven insular worlds with cell-phones and television and Hindi movies-the corrupting elements of current version of modernity, and do not seem interested in taking part in civic life of the village. Many of these practices begin in the cities, and are replicated in the village. Women turn out to be the best anchors of social traditions. 'Rokkhonsheel holo matrijati'the mother race is the most conservative, they hold onto whatever is valuable. Time will move forward and things will change on their course, but one must preserve things of the past as they do in museums. If they don't, then people will lose their roots, their sense of self. The ethos of sacrifice has gone. Persons who have done well economically and gained affluence and recognition have left Maju for the city. But Maju itself is also feeling the vibrations of the city-many forms of transport like auto, trekker, two-wheelers have made spaces more connected, hence, the phenomena of the city can easily find its way into the village. Many of the lower castes-Ontyojo-are able to feed themselves, their children earn from a range of sources. Many migrate to Maharashtra and Gujarat to work in jewelry-making and zari. ${ }^{22}$ Middle-classes are suffering because the only way for them to earn is through application of school and college education and such jobs are often too competitive, so many middle-class youth are unemployed. Kids often go to cricket camps, but will not spontaneously play with other boys of the village on the field.

The Ghosals' account of social change in Maju invokes an inside-outside divide. They do not criticize youth who migrate to western India on the trail of the zari (embellishment of textile, especially saris-an artisanal trade widely practiced in Howrah) economy. They congratulate the lower castes for having pulled up, and lament the impasse in which the village middle-classes find themselves. Economic upliftment must not be at the cost of discarding one's role in society and community, they argue. The voluntaristic traits are disappearing. The public domain of an economically fragile village is used to garner moral strength. The educated class that has remained in the village provides such moral vocabulary of self-sacrifice. Maju has been a nerve-center of cultural life as also nationalist activity, assert the Ghosals. In a space that is beginning to feel the impact of inroads of agents of economic change, the Ghosals published the nitty-gritties of forgotten folk culture in their magazine Kaushikir Totorekha named after a local river, which was proudly pointed out to me from the main walkway-a dried rivulet lined with waste. The speaking subjects of Maju were using the river's metaphorical force to reinforce walls of pride and value around them.

21 It is to this Kaushiki waterway that Ghosal links the history of Maju modernity, in an essay: ${ }^{23}$

Kaushiki nodi o kana damodorer teereei jonopoder kono aek sthhane jogodbollobhimatar mondir chhilo. Oi mondirer namanushaare oi oncholer naam hoy jogodbollobhpur. Ditiyiototoh sholo shotoker sheshpode moghole shomrat 
akbarer (1556-1606 AD) shenapoti maansingh, rajoshyo adayer shutre barojone omatyo shoho gourigaang (odhunolupto) probahopothhe borgachhia onchole haantal onnontobati- bohariyar kono ak sthhane chhouni phaelen. Shenapoti Maansingher namanushaare shrishti hoy Maansinghopur, shontoshsingher naame shonstoshpur ebong Maansingher putro Jogotsingher naame praacheen mamdanipurer naam rakha hoy jogotbollobhpur. Sholo shotoke Jogotbollobhpurer shomridhhir onnotomo kaaron ei jonopode, Kaushikir teere, gore uthhechhillo 'maajher gaa bondore'.

Translated:

... on the banks of the Kaushiki river or the Kana Damodar, there was a temple of the Jogotbollobhi goddess. It was after this temple and its deity that the area got its name Jogotbollobhpur. The general of Mughal Emperor Akbar (1556-1606 AD), Mansingh went down the Gourigaang (now non-existent) riverway in the sixteenth century, with a few associates, collecting revenue, and camped in the Borgachhia area. After Mansingh, the village was named Mansingpur, after Santosh Singh was named village Santoshpur and the ancient village Mamdanipur was named Jogotbollobhpur after the son of Mansingh, Jagatsingh. In the sixteenth century, the village acquired the epithet of 'mid-village port' on account of this riverway along the Kaushiki.

The centrality of Maju is framed in the geography of commerce and state power of the Mughal empire and its emperor Akbar, in this short essay that Narayan Ghosal has written about the history of Jogotbollobhpur, the administrative block area in which his home village Maju is ensconced. He writes to reorient the reader towards Maju, pointing out its links with larger motifs of history. He casts a lens in his historical writing that is quite the opposite of the history that champions the small voice and recovers it as separate cosmology from those of larger enclaves of power-imperial or national. Rather Ghosal affirms the closeness and implicit alliance with forces that are the main protagonists of a wider canvas of history-an emperor and his revenue collector. Evoking the Mughal general's walk along the riverway brings a river of meager historical significance to historical focus, and liberates a place from the shroud of anonymity and forgotten-ness into the luminous frame of historical recognition. Instead of recovering a 'small place' from the discursive violence of colonial records, Ghosal makes Jogotbollobhpur pose in the mainframe of history, proximate to Akbar and his official. Ghosal is attuned to the fact that luminosity granted by historical treatment is available only to a few-usually Mughal revenue collectors and the like. The historical proximity to the emperor's official is not only an ingredient in constructing a historical narrative, but reframes Ghosal's and Maju's current political place. The 'place' of a dried rivulet rises to historical luminosity ${ }^{24}$ claiming the attention of current actors of history on the canvases of nation, region and globe.

Hemendro Bandyopadhyay, now in his seventies, has written many books recording things, people, places, texts that can be linked to the landscape administratively chalked as Howrah in the current map of West Bengal. He is a resident of Salkia in north Howrah. He was a schoolteacher and a journalist. Bandyopadhyay begins his historical accounts of Salkia and of Howrah-Salikhar Itibritto ${ }^{25}$ (1982) and Paachsho Bochhorer Howrah ${ }^{26}$ (1992)with a tone of lament. This was a place that housed much political intrigue and administrative action, and now had unfairly been shoved into a shadowy backstage for the main stage of modernity-the metropolis of Kolkata. Bandyopadhyay, in his extensive volume on Howrah (1992), accords some officials and missionaries more respect than 
others for their efforts in engaging with civic life and bringing about improvements (especially, in the domain of education)-going beyond simply furthering the foremost colonial agenda of spread of the imperial rule and consolidation of markets for imperial commerce. The developmental agenda of colonialism spells for Bandyopadhyay a relationship of care and concern that the colonist at times extended towards his subjects, deviating from the broad agenda of control, accumulation and exploitation. He takes great pains to provide a modernist account of Howrah showing the co-existence of different linguistic, ethnic and religious communities and their mutual respect for each other. He assumes a voice of a recorder, historian, a cultural sociologist, as also a neighbor. In his neighborly voice, he garners empathy and fraternity in a collective lament about 'our Howrah'. He takes great care to lend some completion to this sociogeography, listing exhaustively the events through which urban modernity came to the area-the laying of railway lines, the building of the Howrah Bridge, the establishment of missionary schools, the spread of cultural forms otherwise associated with life in the colonial capital Kolkata (theater, art appreciation, traditions of spoken poetry, classical music, sports and so on). Some well-known actors and film personalities originated in Howrah, he records, as did professionals and academics who found recognitions in major urban centers of India and the world beyond. Life in Howrah in the $19^{\text {th }}$ century and early $20^{\text {th }}$ century was abuzz with cultural and political activity, Hemendro Bandyopadhyay shows his readership. It was a worthy twin of Kolkata in its claim to colonial attention. The colonial developmentalist project is approached with camaraderie and empathy by Bandyopadhyay-as they who thought about us too, not simply their own power and profits. The spread of education, railways and urban infrastructure is remembered as the good things done by the colonial ruler. Bandyopadhyay assumes a voice of a peer in his remarks towards the colonizer-evaluating him, chiding when appropriate, applauding him at apt moments. Bandyopadhyay has published a new version of the Salikha (traditional word for 'Salkia') history-titled Salikhar Shekal o Ekal (Now and Then of Salikha), which was published in December 2011. Entities ranging from the dead river Saraswati to cinema actors, businessmen, doctors of the neighborhood, who had gained recognition in the wider world, are listed and celebrated in the book.

The current volume (2011) of the journal published by the Salikha Itishash Pronoyone Shomiti ${ }^{27}$-Ancholik is dedicated to Tagore and scientist Prafulla Chandra Roy. I ask about the focus of their work-is it solely to document lives of significant characters who have been associated with Salkia? No, he says, not only them, but anyone else whose story can have some historical importance-like a businessman who mastered umbrella-making techniques from Japan, and started a roaring business here. We continue talking about the nature of this historical project-of doing 'zonal' or 'regional' history, especially on the theme of striking a relationship between macro and micro. He says, the 'micro' has very little place in the 'macro'. Hence, in encouraging the project of regional history, we can emphasize these little characters and the great things they did without any historical recognition. He too, speaks in the language of seeking historical luminosity for the actors and events of Salkia, his hometown. Who is your target audience? I ask. Shadharone Pathhoke-the ordinary reader, he says, and those who want to do historical research in the future, like MA students. I ask about the overlap of industrial and residential space in Howrah. He says it wasn't so before, Ghusuri was a designated industrial area. Now many jute mills have shut. Those laborers have become petty traders. Bengalis were never good at manual labor, now they have to do it because they are desperate. Why are they not good at it? I ask. There was a rumor that one would get tuberculosis if one worked at a 
jute mill, but of course, precautionary measures were prescribed-like masks and eating bananas. Earlier, Brahmin boys would not work in Bata, ${ }^{28}$ now they do. These days you might see that a janitor will be Bihari, but his supervisor Bengali.

A few months after this interview, I attended a Bijoya Shommeloni programme (celebration of Vijaya Dashami) organized by the Salikha Itihash Pronoyone Shomiti. There was a discussion of the event they were planning in April 2012, in commemoration of the 150th birth anniversary of Swami Vivekananda. They discussed the names of local citizens who would be honored in the event. The suggestion of the name of Shankar, a well-known Bengali novelist, who was born in Howrah but now lives in South Kolkata, triggered some debate. A member of the audience stood up and said he was a high-handed man and did not care for Howrah at all, others said he was ill and a recluse and might not accept. In the end, they decided to keep for their list Howrah residents and folks who were most likely to accept the honor.

Through the colonial official and Mughal revenue collector, Ghosal and Bandyopadhyay suture the 'local history' of an industrially decadent hinterland district to frames of history that enjoy wider recognition and illumination. Their interest is not in telling the story of Howrah in its peculiarity and separateness from mainstream histories of nation, region and globe. Their attempt is one of suturing this 'place' and its narrative onto a larger historical tapestry, in which Howrah is linked to important Bengali figures of the $19^{\text {th }}$ century, as also colonial officials framed in familiarity and friendship. In doing so, they narrate a place that is exonerated from the confines of here and now, and linked to events of wider historical importance.

\section{World in my pocket}

Majid Molla is a known figure in Uluberia town. I was introduced to him at an event at the Uluberia Institute where he spoke about how Uluberia Shundori (comparing Uluberia to a beautiful woman) had become hyper-modern-there were schools, colleges, shops, vehicles and roads here now. He lamented the decay that the institute's library had fallen into. He urged the general public and the political representatives of the Uluberia citizenry to take cognizance of this. He asked me to meet him at his office at Red Cross office in Uluberia Town, close to the station. In his seventies and always clad in the classic white dhoti-kurta, Molla holds a PhD in mathematics that was adjudged externally at the University of Wisconsin. He has now retired from many years of being a professor of mathematics at the Uluberia College. As a CPI(M) member, he has been Vice-President of the District Council, part of the District Red Cross, part of Shorbo Shikhsha Obhijan (Universal Adult Education scheme) and many other social welfare and development initiatives. He expresses cynicism over the poor effects of postcolonial governance, as a basic lack of humanity among the 'backward' people of the country. He points to the absolute lack of fellow-feeling and the prevalence of cruelty in society as something that cannot be explained by Marxist structural explanations of class struggle and so on. $\mathrm{He}$ cites oppression by religious leaders, innate conservatism and lack of progressive thinking, the tendency to take to the immediate pleasures of money, as the main factors influencing the poor condition of Muslim communities.

I accompanied Molla on several of his appearances at public functions, a number of which were in Muslim-dominates villages or town, where his appearance was that of communitarian pride as also the icon of a Muslim modernist imaginary. At an Eid event 
on a fairground in Bauria, in the vicinity of a labor settlement attached to the Bowreah Jute Mill (popularly known as North Mill), Majid Molla spoke passionately about the relevance of Islamic good conduct, in consonance with the ideals of secular modernity. He repeatedly compared the virtues of cleansing through Ramzan with fasts in other faiths (presumably popular Hinduism).

31 I accompanied Molla to a number of blood donation camps, organized generally by village or town clubs. Molla's speech at a blood donation camp in Gongarampur, Uluberia conveyed a range of opinions between cautious embrace and celebration of technological modernity. He traced debates on blood from the sixteenth century lore of Dracula procuring young women to suck their blood and find youth and longevity, to western science of today. It is western science that has taught us, he said, that the injection of blood can revive the sick. He argued for the need to donate blood to assist thalassemia patients, and need for greater awareness about this. Blood, he said, was an indicator of human equivalence-regardless of ethnicity, gender, class, blood of humans can save the lives of other humans. Hence, the project of blood donation could be seen necessarily as one of unifying humanity.

On the strangeness of current times, he said, 'gota prithibi aekhone amar pockete' (the world is in my pocket) because we can connect to 'London-America' through cellular phones in two minutes. For this, he said, we must remember the indelible contribution of the magician of computers, Steve Jobs, who died recently at the age of fifty-six. It is thanks to him that we have cellphones, he says. These motifs-commercialization of women's bodies, need for conservation of natural resources, blood as the great equalizer of humanity and eulogy of Steve Jobs-recur in Molla's speeches. He urges a Muslim community to embrace the fruits of the welfare state in terms of medical and educational services, and practice their faith in consideration of its equivalence and resonance with other faiths. In his speeches were repeated allusions to examples of urbane-nesstechnology, commercialization, speed, urgency, chaos. His rhetoric, of familiarity and skepticism about hyper-modernity and technoscience, acts as a bridge between an inchoate wider world and his parochial, usually Muslim audience of Uluberia and surrounding areas.

Molla's gestures are not primarily aimed at historical actors (unlike Ghosal and Bandyopadhyay) but to those of global importance in the contemporary world. He is especially keen to establish links between himself and his surroundings, on one hand, and actors of the western world, on the other; modern science, Steve Jobs, University of Wisconsin, appear repeatedly in his narrative. He too, like Ghosal and Bandyopadhay, tailors his public performance towards linking the immediate with the faraway, the anonymous with the significant, thus appropriating for his surroundings of Uluberia, a bit of presence in current history that cellphones, computers and Steve Jobs enjoy.

\section{Calling out to the Faraway}

34 Francis Cody, in his study of newspaper-reading practices at the teashop bench in rural Tamil Nadu, argues that a 'nostalgia for the present' is invoked at these reading rituals. Cody writes (2011: 253):

The Teashop Bench produces an effect of being both of this time (they are discussing contemporary events, closely calibrated to very news being reported 
that day in the rest of the paper) and not (they belong to the time of villages and small towns, that can be experienced as something of the past). In his writing the landscape comes to share the steps of the nationalist or the colonist whose large-frame actions and attendant historical location is then appropriated for Howrah. In all of these rhetorical moves, the actor/speaker/writer never frames the interlocutor (Jobs, Mughal subedar or Job Charnock) in a tone of unbridled admiration or disavowal-fitting of a disempowered, native subject, but more as a friend for whom they have mixed feelings, who is chided as also embraced in familiarity. A larger frame of historical time is available to Howrah through the narration of place and history by public figures such as Molla, Ghosal and Bandyopadhyay. Thus Howrah's public domains, where such public gestures are performed, turn into vehicles of history much like Cody's teashop and Bate's political meeting. The publicly emitted spoken word becomes a turgid carrier of historical connection, through which Howrah grows in scale-both in time and space.

\section{Conclusion}

In this article, I read a series of spoken and written works to ferret out the relationship with history, as performed in public gestures, by public figures of Howrah. Public figures of Howrah use public performance to suture individuated sentiment and place-related reflection to the sensibilities of being in a wider world, along a longer time span. The emergence of the public figure, endowed with emotion, moral and political charge, and 
historical orientation serves as a key instrument for cultivation of historical sensibility. They align somewhat with the classic figure of the bourgeois public sphere-affirming ideals of reason, humanism and the ideological architecture for liberal democracy to be instituted. They fashion selves quite differently from the irreverent, confrontation urban subject whose occupation of public space is part of longer battle to wrench resource and opportunity from state mechanisms. These figures do not shape themselves as 'political society' of Chatterjee's description, neither the nonchalant pablik of Kaviraj's description. They could be likened to the members of adda and the other forms of urban expression that Chakrabarty delineates in Provincializing Europe. As this article shows, in accessing history through speech and writing, these public figures share a sharp historical sensibility of the main stages of history and their marginal location in it, being a decadent industrial hinterland on the borders of an erstwhile colonial capital. The historical luminosity available to a Mughal subedar, a colonial official or an American technologyinnovator is sharply felt by Howrah public figures. They try to access and appropriate such historical charge through a range of public gestures. They engineer their words and gestures towards such appropriation, in showing a feigned familiarity with sophisticated technology of a distant world, in fond chiding of a colonial official who had come to their shores, in framing sentiments of everyday life of Howrah in the larger frame of the charged movement of time into the current worlds of techno-modernity. In doing so, they try to access scale of temporal and spatial worlds that they address, and link such scale to their immediate environs. Through public gestures, Howrah comes to inhabit, if in structurally tenuous ways (as trade and commerce, of an older register of economic modernity, are indeed in a state of decay here), worlds of historical importance. Public gestures, thus, form an important vestibule with which to link the immediate to the distant, as a means of everyday historical access in Howrah.

\section{BIBLIOGRAPHY}

Bagchi, Amiya Kumar (1992) 'European and Indian Enterpreneurship', in R. K. Ray (ed.), Entrepreneurship and Industry in India, 1800-1947, New York: Oxford University Press.

Bailey, F. G. (1957) Caste and the Economic Frontier: a Village in Highland Orissa, Manchester: Manchester University Press.

Banerji, Amiya Kumar (1972) West Bengal District Gazetteer: Howrah, Calcutta: Government of West Bengal.

Basu, Subho (2004) Does Class Matter?: Colonial Capital and Workers' Resistance in Bengal, 1890-1937, New Delhi \& New York: Oxford University Press.

Bate, Bernard (2009) Tamil Oratory and the Dravidian Aesthetic: Democratic Practice in South India, Cultures of History, New York: Columbia University Press.

Bayly, C. A. (1983) Rulers, Townsmen, and Bazaars: North Indian Society in the Age of British Expansion, 1770-1870, Cambridge South Asian Studies, Cambridge [Cambridgeshire] \& New York: Cambridge University Press. 
Benhabib, S. (1992) 'Models of Public Space: Hannah Arendt, the Liberal Tradition, and Jurgen Habermas', in Craig Calhoun (ed.), Habermas and the Public Sphere, Cambridge (Mass.): MIT Press. Bandyopadhyay, Hemendro (1982) Salikhar Itibritto, Howrah: Mira Bondopadhyay. Bandyopadhyay, Hemendro (1992) Paachsho Bochhorer Howrah. Kolkata: Laksmi Press. Bandyopadhyay, Hemendro (2011) Salikhar Itibritto-Shekaal o Ekaal, Howrah: Meera Bondopadhyay.

Calhoun, Craig J (1992) Habermas and the Public Sphere, Studies in Contemporary German Social Thought, Cambridge (Mass.): MIT Press.

Chakrabarty, Dipesh (1992) 'Of Garbage, Modernity and the Citizen's Gaze', Economic and Political Weekly, 27(10/11), pp. 541-547.

Chakrabarty, Dipesh (2000) Provincializing Europe: Postcolonial Thought and Historical Difference, Princeton Studies in Culture/Power/History, Princeton \& N.J.: Princeton University Press.

Chakrabarti, Satyesh C. (ed.) (1995) Port of Calcutta: 125 Years, Calcutta: Calcutta Port Trust. Chatterjee, Partha (2008) 'Democracy and Economic Transformation in India', Economic and Political Weekly, 43(16), pp. 53-62.

Cody, Francis (2011) 'Echoes of the Teashop in a Tamil Newspaper', Language and Communication, 31, pp. 243-254.

Chattopadhyay, Swati (2005) Representing Calcutta: Modernity, Nationalism, and the Colonial Uncanny, Asia's Great Cities, London \& New York: Routledge.

Da Costa, Dia (2010) Development Dramas: Reimagining Rural Political Action in Eastern India, New Delhi: Routledge.

Fraser, Nancy (1992) 'Rethinking the Public Sphere: A Contribution to the Critique of Actually Existing Democracy', in Craig Calhoun (ed.), Habermas and the Public Sphere, Cambridge (Mass.): MIT Press.

Goswami, Manu (2002) 'Rethinking the Modular Nation Form: Towards a Sociohistorical Conception of Nationalism', Comparative Studies in Society and History, 44 (4), pp. 770-799.

Habermas, Jürgen (1989) The Structural Transformation of the Public Sphere: An Inquiry into a Category of Bourgeois Society, Studies in Contemporary German Social Thought, Cambridge (Mass.): MIT Press.

Hansen, Thomas Blom (2001) Wages of violence: naming and identity in postcolonial Bombay, Princeton, N.J.: Princeton University Press.

Howrah Chamber of Commerce and Industry (1994) Economic and Social Survey of Howrah, Howrah. Howrah Municipal Corporation (2007) Draft Development Plan, Howrah.

Kaviraj, Sudipta (1997) 'Filth and the Public Sphere: Concepts and Practices about Space in Calcutta', Public Culture 10 (1), pp. 83-114.

Mines, Mattison (1994) Public Faces, Private Voices: Community and Individuality in South India, Berkeley: University of California Press.

O' Malley, L. S. S.; Chakravarti, Monmohan (1912) Bengal District Gazetteer: Hooghly, The Bengali Secretariat Book Depot.

Pandian, Anand; Daud, Ali (eds.) (2010) Ethical life in South Asia, Bloomington; Indianapolis: Indiana University Press. 
Ray, Rajat Kanta (1992) Entrepreneurship and Industry in India, 1800-1947, New Delhi \& New York: Oxford University Press.

Raychaudhuri, Tapan (1999) Perceptions, Emotions, Sensibilities: Essays on India's Colonial and PostColonial Experiences, New Delhi \& New York: Oxford University Press.

Ruud, A. E. \& Price, P.G. (2010) Power and Influence in India: Bosses, Lords and Captains, New York: Routledge.

Ruud, Arild Engelsen (2003) Poetics of Village Politics: the Making of West Bengal's Rural Communism, New Delhi; New York: Oxford University Press.

Sarkar, Sumit (1973) The Swadeshi Movement in Bengal, 1903-1908, New Delhi: People's Pub. House. Sarkar, Sumit; Sarkar, Tanika (2009) 'Notes on a Dying People', Economic and Political Weekly, 44 (26-27), pp. 10-14.

\section{NOTES}

1. The author is indebted to Prof. K. Sivaramakrishnan, Aniket Aga, Uday Chandra, Debjani Bhattacharyya, Prof. Manas Ray whose insights aided the shaping of this article. This article derives from ethnographic research she conducted in Howrah in 2011-12. The author has chosen, with express permission of the persons concerned, to use the real identities of the three main protagonists, whose published writing is referenced in the article, as also the names of places which are referenced in these works and feature in the ethnography. All other identities have been anonymized.

2. For detailed histories of the economic rise and fall in Howrah, and the larger lower Hooghly belt, through industries like jute, engineering and railways, see Bagchi (1992) and Ray (1992).

3. The term 'urban horizon' comes to me from Prof. K. Sivaramakrishnan, who used it in his inaugural address at the 'Social Dynamics of the Urban' workshop at IIAS, Shimla, May 10, 2013.

4. These details are laid out in Socio-Economic Survey of Howrah (1994) conducted and published by the Howrah Chamber of Commerce and Industry.

5. The jurisdictional divisions and overlaps were mentioned to me in interviews by officials at the Howrah Municipal Corporation. The only documentary corroboration I can find for this in the Howrah Development Plans (1962 and 2007) is that the Kolkata Metropolitan Development Authority has general planning jurisdiction over the Howrah city region, which is part of Greater Calcutta.

6. The KMDA has planning jurisdiction over the Urban Local Bodies that are in proximity to the boundaries of Kolkata.

7. Chakrabarti (1995) mentions the silting of the port waters. But I have not found ecological documentation of the river's silting history, around the Howrah channel. Historian Shibendu Manna and others have mentioned this as a cause of Howrah's decline in conversations with me.

8. Habermas' 'public sphere' generated a theory of institutions, outside the state, through which a tradition of critical-rational debate among citizens grew. The earlier traditions of reflection in critical-rational debate give way to production and consumption of 'culture' and 'politics' in the public sphere. The entry of unpropertied collectivities into the public sphere to articulate their 'publicly relevant' claims before state agencies, Habermas claims, strips the public sphere of its original raison d'être, without bringing in a new one (Habermas 1989: 177). Craig Calhoun unpacks various trajectories that the Habermasian 'public sphere' has taken, in his rich introductory essay in Habermas and the Public Sphere. He specifically points out the key moments in Habermas' text that show the gradual delinking of the public sphere from actual state apparatus and its 
configuration into a space and a complex of relationships that are in continuous conversation with state institutions, in the language of critical-rational debate (Calhoun 1992: 8). Habermas' argument is pushed forward by Nancy Fraser, on the lines that recognition in the 'public sphere' as a means to bring about 'redistribution' of resources in the democratic sphere. Seyla Benhabib discusses the formation of new 'private' spheres that speak of and are spoken to by the democratic welfare state (Benhabib 1992: 91-2). Both Fraser and Benhabib hint at the various 'privates' that are demarcated, cordoned off, as well as reproduced as handles in the tussles with the state, in the late capitalist democratic public sphere. Fraser envisages a post-bourgeois public sphere, which is transformed from a 'collection of self-seeking, private individuals into a publicspirited collectivity, capable of acting together in the common interest.' (Fraser 1992: 130). Michael Warner shows, through the example of emergence of 'queer publics', the appropriation and inversion of logics of the public sphere and the making of counterpublics.

9. Bengali appropriation of the English word 'public'. Kaviraj uses it to index the vernacularisation of the notion of 'public', as well as the fall-out of the 'public' from ritual hierarchies prevalent otherwise.

10. Amiya Banerji details the many change of hands that rule over the present-day administrative unit of Howrah has undergone in the West Bengal District Gazetteer: Howrah. This District Gazetteer for Howrah (1972) is a revised edition of the earlier Gazetteer (O' Malley \& Chakravarti 1912). In 1760, Howrah and Burdwan were ceded to the East India Company by Mir Kasim. In 1843, the government appointed a Magistrate for the territory comprising of Sulkea, Oolooberia, Ampta and a few other places, which remained attached to the 24 pergunnah district. Not until December 8, 1937 did Howrah become a full-fledged, independent district (Banerji 1972: 6-7).

11. See the next footnote.

12. In May 2011, the three-decade Left Front regime (headed by the CPI(M)) was voted out of power. Mamata Banerjee, who had started a new party-the Trinamool Congress-having defected from the Congress, espoused a program of 'poriborton' (Bengali for 'change') against the moods of abyss and deadlock that prevailed in public cultures of West Bengal in response to the Left Front's inability to access the routes of progress as other states did, in post-liberalisation India. The Singur and Nandigram land conflicts in the years preceding the fall of the Left Front were triggers in shifting the balance of public opinion against the Left Front in the mainstream media as also the left intelligentsia (see especially, Chatterjee 2008; Sarkar \& Sarkar 2009).

13. Durga Puja, the main festival of Bengalis, usually observed in October, also held as important for the proliferation of cultural and literary initiatives like little magazines, release of music albums, annual issues of magazines during or immediately after the Pujas. Dashami, or Vijaya Dashami, is the last day of the five-day celebrations-the day that marks the goddess' annihiliation of the demon Ashura.

14. The magazine had to add an 'ebong' (Bengali for 'and') to its name, as the mouthpiece of the ruling party Trinamool Congress carries the name Ma, Mati, Manush (translated: Mother, Land, Man).

15. Title of a magazine. It literally translates as 'time literate'.

16. A Bengal handloom, with which saris are made. The name derives from a place in East Bengal (now Bangladesh).

17. Bengali sweets and savory snacks served at social events.

18. The word Shotta translates approximately in English as 'self'.

19. Popular epithet for the new Chief Minister, Mamata Banerjee, who also heads the Trinamool Congress Party.

20. The title of the newspaper would translate in English as 'The Banks of Kaushiki'.

21. A rural theater tradition prevalent in Bengal, usually known for its tradition of baroque and melodramatic theater. 
22. Traditional textile used to embellish garments like saris. The zari economy was widely present in the Uluberia- Bagnan stretch, and to a large extent, among Muslim communities. Young men often traveled to western India or to the Gulf countries on jobs concerning zari commerce. Zari, it was said, had made many young men suddenly rich. Many told me that zari was worked on at home by women and men over long hours, through which they played music on radio or stereos to alleviate monotony, and that this was a cause of social decline.

23. Ghosal, Narayan. 2010. Jogotbollobhpurer Shobhyota o Shongoshkriti. Jogotbollobhpur, Howrah.

24. The term 'historical luminosity' comes to me from Prof. Manas Ray in personal conversations in 2012.

25. A Synopsis of Salikha.

26. Five hundred years of Howrah.

27. The history-writing group, based in Salkia, headed by Hemendro Bandyopadhyay.

28. A well-known shoemaking company-the reference here, being working in Bata would equal working with leather, a profane activity.

\section{ABSTRACTS}

This article narrates events, performances and gestures from public life on the rural-urban corridors of Howrah District, on the west bank of the river Hooghly, in southern West Bengal. Howrah is a place of decadent industrial activity, owing much of its spatial organization to colonial manufacture and trade on the edges of the colonial capital of Calcutta. Public figures in Howrah attempt to lift a place and an associated public out of its current political and historical anonymity. Each uses public gesture to appropriate distant phenomena, quite far-fetched and tenuously linked to their immediate existence. Such public gesture emerges as a key tool for gaining historical luminosity. Their words, gestures and stances are used to access history and historical significance, linking the historical charge of distant entities to immediate worlds, and aiding access to larger scale in space and time.

\section{INDEX}

Keywords: public figure, public, urban, history, space, scale, economy, memory

\section{AUTHOR}

\section{ATREYEE MAJUMDER}

$\mathrm{PhD}$ candidate in political and historical anthropology, Yale University 